\title{
Social economic life of oil palm farmers
}

\author{
Rahmanita ${ }^{1}$, Fatmariza ${ }^{2}$, Buchari Nurdin ${ }^{3}$ \\ 123 Universitas Negeri Padang, Padang - Indonesia, (rahmanitaunp@gmail.com)
}

\begin{abstract}
Socio-economic conditions of oil palm farmers will affect the income and education of children. The purpose of this study to describe socio-economic life of oil palm farmers since 1996-2016 and their changes of life, and their developmental impact on the education of Jorong Silawai children. This study uses historical research methods, namely Heuristik, source criticism, interpretation, and Histroriografi. The results of the study found that the impact of the presence of oil palm companies on the economic condition is very influential that after the existence of the company than before the company. Oil palm farmers who previously farmed to meet their daily needs, with PT BTN's plasma plantations could be an additional source of additional farming. Revenues from PT BTN's plasma plantations are varied. The main factors that influence it are fluctuations in palm oil prices. Oil palm growers also get producers from other work. Revenue from PT BTN's plasma plantations is not possible to fulfill their life. The low awareness of farmers on the education of their children. Here is demanded the role of government in improving socio-economic conditions of oil palm farmers so that it will have an impact on the awareness of farmers on the education of their children.
\end{abstract}

Keywords: product, price, distribution, promotion, buying decision.

\section{Introduction}

The agricultural sector plays an important role in the national economy, because in addition to providing food for the entire population, this sector also contributes foreign exchange, provides employment opportunities and supports the development of other sectors, especially in the provision of raw materials for industry. In the Indonesian economy small business sector plays a very important role, especially when associated with the workforce that can be absorbed as a workforce. Thus the people's economy like this can help the government to reduce unemployment, helped accelerate the national economic growth, and play an important role in industrialization. In addition to having strategic significance for development as well as efforts to maintain the results of development that has been achieved (Panji, 2009: 44).

Sungai Beremas District is one of the sub-districts in Pasaman Barat district where the capital of the sub-district is located in Aia Bangiah. In the River Beremas district there are several jorong which one of them is Jorong Silawai. The eyes of the Jorong Silawai community are generally farmed, looking for wood in the forest, and some are farm laborers, chilli and vegetable gardening to meet the daily needs of life. 
In general, the economic life of Silawai jorong community is still low, which is seen from the number of people in Silawai jorong only graduated to junior high school level (Sekolah Menegah Pertama) and dropping out of school. Nevertheless Silawai jorong society is hardworking, they are not only fixated on one job, but have job or other source of income. This is reflected in the conditions of their economic lives as if they are still very poor that can be observed on the fulfillment of clothing, food, and boards. Although their income is large but their minimum standard of living is still apprehensive such as low quality of fulfillment of basic needs and so on.

The economic condition of the oil palm farmers in Jorong Silawai and the uncertain amount of income caused the education awareness in Jorong Silawai to remain low. This will affect the level of education of children of oil palm farmers in Jorong Silawai. Based on the background, this research aims:

1. To describe socio-economic life of oil palm farmers since 1996-2016 and its changes to life.

2. To describe the development of children's education of oil palm farmers in nagari Jorong Silawai.

\section{Method}

This study is a historical review of the existence of oil palm plantation Jorong Silawai using the socio-economic approach. This research uses historical method. The historical method is an investigation that applies the scientific method of solving from the perspective of a problem's hitoris. The historical method is a process of collecting and interpreting past phenomena, events or ideas to find useful generalizations about the activities of history. The basic systematic principles used.

This research was conducted in Jorong Silawai, Sungai Beremas District, Pasaman Barat Regency.The research informants consisted of nine respondents namely Wali Nagari, Jorong Head, PYT BTN Staff, and local community.

\section{Research Findings}

\section{Socio-Economic Life of Oil Palm Farmers in Jorong Silawai}

The existence of oil palm plantations in the midst of Jorong Silawai community is directly or indirectly has brought various influences or impacts on the socio-economic conditions of the community, especially around the PT BTN Plantation. Positive impacts such as opening new fieldwork, transportation access more smoothly with the opening of new roads, and the existence of social activities of the company. In addition, negative impacts such as land conflicts, adat conflicts, and environmental issues. With the development of oil palm plantation in Jorong Silawai also give influence on socio-economic condition especially on work and income of Jorong Silawai citizen especially plasma farmer. The socio-economic changes of Jorong Silawai people, especially Jorong Silawai plasma farmers, are seen from the work, and the development of children's education.

Viewed from the type of people's livelihood. The influx of oil palm companies influences people's livelihoods, some residents decide to convert their land into gardens, especially oil palm, so that the number of oil palm plantations in Jorong Silawai is increasing. The existence of plasma plantations also facilitates people who have land for oil palm plantations that help by partner companies in the management and marketing of the results to partner companies so as to facilitate plasma farmers in managing the garden.

Jorong Silawai is an area where there are many plantations that have a total area of about $4.988 \mathrm{Ha}$. In accordance with the extent of land use in this area is very diverse, such as settlements, farmland, and others. In essence, farmers in selling their products in the form of palm oil should be able to achieve the expected profit. Because profit is the main objective in agricultural activities. Sales do not guarantee the farmer to earn a profit. This is due to the sales revenue should still be deducted by the 
costs incurred by farmers in producing their production such as fertilizer costs, labor and transportation wages. If the sale is less than the costs incurred the farmers will lose.

The existence of PT BTN in oil palm plantation activities in Jorongi Silawai enough to affect the economy of the community, especially the people who are members of the plasma plantations that feel a direct change to the existence of PT BTN. The change felt by Jorong Silawai community is directly or indirectly. The change felt by the community over the existence of PT BTN is the opening of field work especially for the foreman, picker and plant maintenance. The opening of employment indirectly reduces unemployment, so the economy of the surrounding community is getting better.

Viewed from the income of farmers, oil palm plantation development activities provide external influences that are positive or beneficial to the surrounding area. The benefits of this plantation activity on the economic aspects of rural areas, among others: 1) Expanding employment and business opportunities; 2) Increasing the welfare of surrounding communities; and 3) Contributing to regional development.Palm Oil Farmers in Jorong Silawai who are members of plasma farmers of PT BTN have income ranging from Rp 1,200,000 ?? Rp 2,500,000 per Ha of land. While in 2010 the income of plasma farmers.in Jorong Silawai ranged from Rp. 558.000 ?? Rp 1.250.000. Increasing the amount of income will provide more prosperity for smallholders.Jorong Silawai community in addition to work can also learn from the plantation is how to grow crops, and fertilization so that it can produce good plants. plasma farmers of PT BTN have side jobs outside of oil palm plantations, and their work varies. Farmers do work that suits their abilities. In addition, there are farmers who earn extra income from the wife's business. They need more income to meet their daily needs and school fees for their children.The direct impact of the surrounding community is the opening of field work in oil palm plantation activities.

The opening of employment indirectly reduces unemployment, so the economy of the surrounding community is getting better. The indirect impact of PT BTN's plasma plantations is the opening of new jobs outside the plantation, such as the emergence of shops, stalls, workshops, food stalls, and other businesses coming from the family of oil palm farmers or Jorong Silawai community.Seen from the changes that occurred after the existence of Palm Oil Plantations in Jorong Silawai there are Pro Cons of Palm Oil Development based on various opinions and observations. Meanwhile, if viewed from a different point of view, there are some opinions of citizens with the presence of palm oil in jorong Silawai. Some important points of oil palm plantations in Jorong Silawai are:1) Collide with some areas that are Protected Forest. 2) The potential for social conflict, with migrant workers from other areas of different socio-cultural differences from indigenous peoples. 3) The occurrence of horiziontal and vertical conflicts due to the entry of oil palm plantations. 4) There is potential for conflict between the surrounding communities as they are fighting over claims over the ownership of the open areas as oil palm plantations. 5) The transfer of forest functions leads to loss of timber value and environmental damage. 6) The level of illegal logging is increasing. 7) May threaten the existence of water sources because the border area is a catchment area and water pockets. 8) Occurs siltation in the rivers due to natural damage. 9) Natural biodiversity will be lost due to the clearing of plantation land.

Prior to the establishment of PT.BTN most of the educational conditions of the community in Jorong Silawai with $36.3 \%$ did not complete primary school because society still not prioritize education only work for the needs of daily life. But until now, the level of concern of oil palm farmers in Jorong Silawai is still relatively low because farmers are still thinking about fulfilling the necessities of life when the price of palm oil declines and farmers tend to be consumptive to buy goods that are not necessities at the time of high palm prices, but many farmers does not prioritize his children's education at the time of high palm oil prices. 


\section{Results and Discussion}

\section{The Socio-Economic Life of Oil Palm Farmers Since 2004-2016 In Jorong Silawai}

The development of oil palm plantations has a positive impact on local communities, such as creating employment opportunities for the community. This opportunity then also opens opportunities for people to make businesses such as food kiosks, transportation and home industry. Income and welfare levels of the community increase along with the emergence of traditional markets in residential areas as well as the pattern of consumption and public education that will also increase.

The development of oil palm has two main objectives, the first being for the development of oil palm in Jorong Silawai, creating jobs and improving the welfare of the community. The second is to improve the education of children in Jorong Silawai. These two goals are in line with the objectives of development. The benefits of plantation activities on socio-economic aspects include: 1) Increasing the welfare of surrounding communities; 2) Expanding employment and business opportunities; 3) Contributing to regional development (Irsyadi, 2015).

Society should be able to capture potential business opportunities in order to make it an effort that can make additional income for the community itself. The ability of people to capture opportunities will affect their ability to take advantage of opportunities. It also requires the ability to organize resources so that the opportunity becomes a business that operated in actual. It is necessary that collaborative government policies and community capacity will determine the variation of income sources through plantation development. Community economic independence is strongly influenced by factors inside and outside the community itself. In the long run, the two factors above are more of a historical approach, namely that the available resources are given, that is the case (Supartono, 2011).

Jorong Silawai community felt the direct and indirect impact of PT BTN's existence. Communities belonging to the plasma plantations have a direct impact on the economy. The next immediate impact is the opening of business fields for foremen, pickers and cultivators. Indirect and indirect impacts are reduced unemployment from the opening of jobs which then improve the economy of the community. Indirect impact because of this job is also in the form of the emergence of shops or shops and workshops outside the plantation.Significantly, social impacts arise due to the expansion of oil palm plantations, ie land conflicts between companies and indigenous peoples, farmers and oil palm plantation workers. This conflict often leads to violence that results in criminalization and demos to the government, such as the case of expansion of the area of Oil Palm Plantations outside of Hak Guna Usaha (HGU).

The private sector is accompanied by the district government to grant an unconventional permit to expand oil palm plantations resulting in farmers' lands or communities inside the permits and outside the HGU cleared by the company into palm plantations.Communities do the destruction and removal of plants in the company's garden is not without reason, because the farmers' dissatisfaction over the land. They have filed an objection to the designated agency, but the report is ignored and slow to work on. Moreover reports of destruction of palm oil plantation companies are responded to by criminalizing the perpetrators of the perpetrators. The income of the community before and after the plantation activities has varied changes. Plasma garden revenues are the result of a reduction in plasma plantation revenue at the cost. Revenue of plasma plantation from palm oil production of 2 Ha multiplied by the price of oil palm received by PT BTN. Fees consist of cash and non-cash costs (fees are taken into account). Cash costs incurred are cost management, road maintenance, transport costs, pest and disease eradication, fertilizer and leaf analysis, mandatory savings, replanting, PBB, social funds, labor wages, equipment and credit installments.

The non-cash costs incurred by plasma estates are depreciation of crop yield, depreciation of equipment and lease of land.The Jorong Silawai community involved in plasma plantations generally have a goal to increase plasma plantations. The income of plasma farmers each month differs 
depending on the fluctuation of world palm prices. Average ranges from $\mathrm{Rp} 1,000,000$ and $\mathrm{Rp}$ $5,000,000$. This encourages oil palm farmers to run other businesses to supplement their income, such as opening a shop business, planting other commodities and raising livestock. Even the wives and children of the farmers also open businesses to support their family's economy.

In addition, the community when still in the area of origin cultivates food crops in the form of paddy rice and palawijaya and other crops such as rubber and coconut which decision-making system is entirely in the hands of the farmers themselves, after they have to carry out the business of palm oil plant industry which decision-making system is completely in the hands of farmers. And applies market mechanisms as well as commercialization of the products that are produced (Syapsan, 2010).

Since plantation activities provide employment opportunities for people in the area around the plantation, it turns out to have a positive impact on people's income. As the development of oil palm plantations, the impact will be more on the workforce working in the plantation sector and its derivatives sector. The impact can be seen from the increase of farmer's income, so that the increasing of rural people's purchasing power, for both primary and secondary needs (Laing, 2016).

The emergence of new businesses managed by the community is one thing that also needs to be observed. In general, with the plantations leading to the emergence of new sources of more varied incomes. The change is prior to the opening of the plantation, the community relying its income on the primary sector such as the utilization of natural resources relative without using technology. Communities around the river water in general work as fishermen and wood searchers in the forest. The orientation of the business is also limited to meeting the needs of the family for the next one or two days without a clear business development plan. According to Imam (2013) The existence of industry in a region will certainly bring changes and influence on the livelihood of local communities.

Based on the results of research Irsyadi (2015) showed oil palm plantations contribute greatly to the income society. The contribution will be greater if the area of development is greater, as well as the level of production. The higher the productivity level of farmers will lead to higher production in scale.

Development Oil palm plantations have a double impact on the region's economy, particularly in creating opportunities and employment opportunities. The development of this oil palm plantation has benefited, so it can expand the spreading power to the surrounding community. The growing development of oil palm plantations, the more impact it has on the workforce working in the plantation sector and its regional derivatives (Muad, 2016).

The expansion of oil palm plantations has the potential to provide economic benefits, but can lead to environmental disturbance (Rany, 2017). In addition to the positive impacts, there are also negative impacts resulting from the development of oil palm plantations. Each sale must achieve the expected profit, but in this case does not guarantee the farmers get a profit because the sale of this must be deducted costs that must be incurred by farmers. These costs include the cost of fertilizer, labor wages, and transportation. If the sale is less than the costs incurred the farmers will lose.The existence of PT BTN and its plantation activities creates both positive and negative impacts on the community and neighborhood around Jorong Silawai. With the breeding of agricultural areas, bringing serious changes to the natural ecosystem. The destruction of nature to open the land has caused pollution, consequently public health and animals and plants around the area decline.The existence of oil palm plantations not only resulted in ecological damage, but also socio-economic community, especially food farmers. Land use change results in changes in tana patterns, food farmers. Other crops and horticultural cropping patterns that are not simultaneous due to the impact of expanding the area of perennials, especially oil palm, bring risks to farmers who still survive in food crops and other horticulture. 
The next problem is the occurrence of agrarian conflict with various conflicts. The problem is a conflict between indigenous peoples and plantations, employees with companies and landowners with the government. In addition, conflicts can also widen into communities with governments, corporations with governments, communities and communities. In addition there is also corporate conflicts with companies concerning the granting of land permits overlap.

Impact of Oil Palm Plantation Development on Child Education Nagari Jorong Silawai

With the government's attention to education, educational facilities in Jorong Silawai can be said complete with the attention of facilities from kindergarten to high school level or equivalent. Based on the results of research Lisa (2016) states that the availability of affordable service facilities by the community can facilitate the community to get education.

Prior to the existence of PT BTN, 36.3\% of Jorong Silawai people did not complete primary school because they only work for daily needs and have not put education as a priority. However, the farmers' awareness for education is still low since they are still considering the priority of fulfilling the necessities of life when the price of palm oil declines and the farmers tend to buy goods that are not a priority for everyday life compared to the education of their children when the price of oil palm is high. In addition, the research results Martha (2012) showed environmental factors and the work of parents can mempengruhi education level of his family. Parental income also affects awareness of the importance of education (Nina, 2016).

Prior to the existence of PT BTN, 36.3\% of Jorong Silawai people did not complete primary school because they only work for daily needs and have not put education as a priority. However, the farmers' awareness for education is still low since they are still considering the priority of fulfilling the necessities of life when the price of palm oil declines and the farmers tend to buy goods that are not a priority for everyday life compared to the education of their children when the price of oil palm is high. In addition, the research results Martha (2012) showed environmental factors and the work of parents can mempengruhi education level of his family. Parental income also affects awareness of the importance of education (Nina, 2016).

Not all farmers are less concerned about the education of their children, there are also farmers who send their children to the college level. But there are still some who do not even send their children to school and choose to take their children to be farmers even though the child is still in compulsory education. Parents have an important role in children's education. The role of parents in the education of children in the form of moral encouragement, personality shaping and facilitator. Parental moral drive as a guide and motivation.The level of education can affect one's thinking, especially in analyzing a problem. A well educated person will be easy to adopt new technology, develop skills, and solve problems encountered. The tendency that exists, the higher the level of education someone, the more responsive the person to change? change (Kadir W. 2012).PT BTN plays a role in improving education but is limited to monthly employee families such as office staff, foremen, and factory employees.

With the high cost of education, burdens Jorong Silawai people who only rely on agriculture sector. So that the children of the plasma farmers are not many who completed the 9-year education coupled with fluctuating palm prices. For casual laborers, their daily wages depend heavily on the circumstances of PT BTN making them deficient in meeting the educational needs of their children.

The government should have an important role in raising awareness of education for oil palm farmers. The government has not made the program clear, the government should approach the oil palm farmers to raise their awareness about the importance of education.

Educational development needs to include "self-educational empowerment" and "community empowerment". The educational development policy that has been more likely to be given meaning by the government and gives little discourse for the community to participate in discussing and 
conveying the "view from below". The community is "marginalized" almost in every educational / school decision.

\section{Conclusions}

In this study the authors looked at the impact of oil palm companies in the social and economic aspects that are visible from work, income, and education factors. Based on the results of research and discussion, it can be concluded that the impact of the existence of oil palm companies to economic conditions are affecting the company after the company compared before the company. Oil palm farmers who previously farmed to meet their daily needs, with PT BTN's plasma plantations could be an additional source of additional farming.

Revenues from PT BTN's plasma plantations are varied. The main factors that influence it are fluctuations in palm oil prices. Oil palm growers also get producers from other work. Revenue from PT BTN's plasma plantations is not possible to fulfill their life.

The low awareness of farmers on the education of their children. Here is demanded role of government in raising awareness of farmer to education of child. The government has not been maximally in running the program, judging by the low number of learners at the secondary school level.

The existence of a plasma plantation in Jorong Silawai provides employment opportunities for people in the area around the plantation, it has a positive impact on people's income. The development of plasma plantations has a double impact on the region's economy, particularly in creating opportunities and employment opportunities. The emergence of new businesses managed by the community is one of the changes that occurred. Generally, with plasma plantations, new sources of income are increasingly varied, which can increase the income of smallholders. In addition, indirectly earnings of plasma farmers have an impact on the education of their children. The support of PT BTN and the Government should play an important role in raising awareness of education for oil palm farmers in Jorong Silawai.

\section{References}

Kadir, W. (2012). “Analisis Kondisi Sosial Ekonomi Masyarakat Sekitar Taman Nasional Bantimurung Bulusaraung, Provinsi Sulawesi Selatan". Jurnal Manusia dan Lingkungan, Vol. 19, No.1

Basri. (2006). Metode Penelitian Sejarah (Pendekatan, Teori dan Praktik). Jakarta : Restu Agung

Imam, N. (2013). "Pengaruh Keberadaan Industri Terhadap Kondisi Sosial Ekonomi Dan Budaya Masyarakat Desa Lagadar Kecamatan Marga Asih Kabupaten Bandung". Jurnal Sosietas, Vol. 5, No. 2.

Irsyadi, S. (2015). @Dampak Perkebunan Kelapa Sawit Terhadap Perekonomian Wilayah Di Kabupaten Rokan Hulu. Jurnal Agroteknologi, Vol. 5 No. 2

Lisa, F. (2016). @Identifikasi Kondisi Sosial Ekonomi Penduduk Di Kelurahan Kelayan Luar Kecamatan Banjarmasin Tengah. Jurnal Pendidikan Geografi Volume 3, No 2.

Martha, W. (2012). Keadaan Sosial Konomi Masyarakat Nelayan Di Desa Kinabuhutan, Kecamatan Likupang Barat. Kabupaten Minahasa Utara, Sulawesi Utara. Pasific Journal Vol. 1(7).

Muad, R. (2016). "Dampak Sosial dan Ekonomi Aktifitas Perusahaan Perkebunan Kelapa Sawit PT. Gawi Makmur Kalimantan di Desa Rintik Kecamatan Babulu Kabupaten Penajam Paser Utara". Ejournal Ilmu Pemerintahan, 2016, 1 (1): 12-25

Nina, SS. (2016). Kesadaran Masyarakat Nelayan terhadap Pendidikan Anak. Jurnal Ilmu Pemerintahan dan Sosial Politik 4 (1) (2016): 1-10 
Nurwalidiniati. (2017). ๑Dinamika Kehidupan Petani Tambak Di Kecamatan Jangka Kabupaten Bireuen, 1960-2015๑. Jurnal Ilmiah Mahasiswa (JIM) Program Studi Pendidikan Sejarah Volume 2, Nomor 1

Panji, A. (2009). Manajemen Bisnis. Jakarta: Rineka Cipta.

Rany, U. (2017). “Dampak Ekonomi dan Lingkungan Ekspansi Perkebunan Kelapa Sawit”. Jurnal Ilmu Pertanian Indonesia (JIPI), Vol. 22(2): 115-126

Supartono. (2011). ๑Analisis Pengaruh Variabel Sosial Ekonomi Masyarakat Urban Terhadap Kemandirian Ekonomi Ditinjau Dari Aspek Keuangan, Energi, Dan Pangan Di Kecamatan Singosari Kabupaten Malang®. Journal Of Indonesian Applied Economics Vol. 5 No. 1 Mei 2011, 4456

Syapsan. (2010). "Perubahan Sosial Masyarakat Pasca Pembangunan Pembangkit Listrik Tenaga Air (PLTA) Koto Panjang Provinsi Riau". Jurnal Ekonomi Volume 18, Nomor 2. 